OPEN ACCESS

Edited by:

Jan Kofod Schjoerring,

University of Copenhagen, Denmark

Reviewed by:

Victoria Fernandez,

Technical University of Madrid, Spain

Elke Bloem,

Julius Kühn-Institute - Institute for Crop and Soil Science, Germany

*Correspondence:

Tae-Hwan Kim

grass/@ chonnam.ac.kr

${ }^{\dagger}$ These authors have contributed equally to this work.

Specialty section: This article was submitted to Plant Nutrition,

a section of the journa Frontiers in Plant Science

Received: 07 January 2016 Accepted: 24 March 2016 Published: 08 April 2016

Citation:

Lee B-R, Zaman R, Avice J-C Ourry A and Kim T-H (2016) Sulfur

Use Efficiency Is a Significant

Determinant of Drought Stress Tolerance in Relation to Photosynthetic Activity in Brassica napus Cultivars.

Front. Plant Sci. 7:459. doi: 10.3389/fpls.2016.00459

\section{Sulfur Use Efficiency Is a Significant Determinant of Drought Stress Tolerance in Relation to Photosynthetic Activity in Brassica napus Cultivars}

\author{
Bok-Rye Lee ${ }^{1,2 t}$, Rashed Zaman ${ }^{1 \dagger}$, Jean-Christophe Avice ${ }^{3,4}$, Alain Ourry ${ }^{3,4}$ and \\ Tae-Hwan Kim ${ }^{1 *}$ \\ ${ }^{1}$ Department of Animal Science, Institute of Agricultural Science and Technology, College of Agriculture and Life Science, \\ Chonnam National University, Gwangju, South Korea, ${ }^{2}$ Biotechnology Research Institute, Chonnam National University, \\ Gwangju, South Korea, ${ }^{3}$ Université de Caen Basse-Normandie, Caen, France, ${ }^{4}$ UMR INRA-UCBN 950 Ecophysiologie \\ Végétale, Agronomie et Nutritions N, Université de Caen Basse Normandie, Caen, France
}

To investigate the varietal difference in sulfur use efficiency (SUE) and drought stress tolerance, Brassica napus 'Mosa' and 'Saturnin' were exposed to polyethylene glycol (PEG)-induced drought stress for $72 \mathrm{~h}$. Direct quantification of $S$ uptake, de novo synthesis of amino acids and proteins was performed by tracing ${ }^{34} \mathrm{~S}$. The responses of photosynthetic activity in relation to SUE were also examined. The total amount of newly absorbed $S$ decreased with drought stress in both cultivars but the decrease rate was significantly higher in Mosa (-64\%) than in Saturnin (-41\%). Drought stress also decreased the amount of $S$ assimilated into amino acids ( ${ }^{34} \mathrm{~S}$-amino acids) and proteins ( ${ }^{34}$ S-proteins). The total amount of $\mathrm{S}$ incorporated into amino acids and proteins was generally higher in Saturnin (663.7 $\mu \mathrm{g} S$ per plant) than in Mosa (337.3 $\mu \mathrm{g}$ S per plant). The estimation of SUE based on S uptake (SUpE) and S assimilation (SUaE) showed that SUE was much higher in Saturnin than in Mosa. The inhibition of photosynthetic activity including Rubisco protein degradation caused by drought stress was much lower in the cultivar with higher SUE (Saturnin). The present study clearly indicates that the genotype with higher SUE is more tolerant to PEG-induced drought stress.

Keywords: Brassica napus, PEG-induced drought stress, photosynthetic activity, ${ }^{34} \mathrm{~S}$ tracing, sulfur use efficiency

\section{INTRODUCTION}

Oilseed rape (Brassica napus L.) is increasingly grown throughout the world. It has a wide range of uses including vegetable oil, animal feed, and alternative fuel (Abdallah et al., 2010). Oilseed rape is also considered to be an excellent rotation crop which enhances suppression of soil-borne pathogens and a catch crop species that limits leaching of mineral nutrients into the aquifer (Kirkegaard et al., 1997). World production of oilseed rape is growing rapidly, with FAO reporting

\footnotetext{
Abbreviations: $\Psi_{w}$, leaf water potential; GSH, Glutathione; NAS, Newly absorbed S; NUaE, N assimilation efficiency; NUpE, N uptake efficiency; PEG, Polyethylene glycol; RSA, Relative specific activities; SUaE, S assimilation efficiency; SUE, Sulfur use efficiency; SUpE, S uptake efficiency.
} 
that 47 million tons of oilseed rape was produced in 2007, and 58.4 million tons estimated to have been produced in the 2010-2011 (Saeidnia and Gohari, 2012).

In general, oilseed rape, and Brassica species have a characteristically high sulfur (S) demand during vegetative growth for the synthesis of proteins. For example, the production of 1 ton of rape seeds requires about $16 \mathrm{~kg} \mathrm{~S}$ (Blake-Kalff et al., 2001), compared with $2-3 \mathrm{~kg}$ of $\mathrm{S}$ per ton of wheat grain (Zhao et al., 1999). Moreover, these plants contain relatively high amounts of S-containing secondary metabolites, viz. glucosinolate, which accounts for up to $20 \%$ of the organic sulfur content (Castro et al., 2004; Aghajanzadeh et al., 2014). However, S-deficiency is a common phenomenon in many agroecosystems, caused by a massive decrease of $S$ inputs from atmospheric deposition and reduced application of S-containing fertilizer in the last three decades (Zhao et al., 1997). S-deficiency and/or S-deprivation decrease the cell sap osmotic potential due to a net increase of intracellular solutes, rather than from a loss of cell water (Kusaka et al., 2005). In addition, S-deficiency reduces chlorophyll and Rubisco content, and provokes chlorosis of young leaves (Gilbert et al., 1997; Lee et al., 2014; Muneer et al., 2014). These results imply that S-deficiency results in a general inhibition of photosynthesis and protein synthesis. In B. napus, studies carried out under controlled greenhouse (Balint and Rengel, 2008; Dubousset et al., 2010) or field conditions (Schnug et al., 1993; Fismes et al., 2000) have shown that S-deficiency reduces $\mathrm{N}$-use efficiency, and that $\mathrm{N}$-deficiency can also affect the S-use efficiency. Under S-deficiency conditions, a reduction in the internal S pools and an increase in soluble nitrogen content, including nitrate and amides, have been observed (Prosser et al., 1997; Warrilow and Hawkesford, 1998). In B. napus, our recent work with ${ }^{15} \mathrm{~N}$ and ${ }^{34} \mathrm{~S}$ tracing revealed that the total amount of $\mathrm{N}$ and $\mathrm{S}$ incorporated into proteins decreased by 28.8 and $62.1 \%$ under S-deficiency conditions (Lee et al., 2013). Our work also showed significant modification of the partitioning of newly absorbed $\mathrm{N}$ and $\mathrm{S}$, and remobilization of stored $\mathrm{N}$ and $\mathrm{S}$, in S-deficient plants (Lee et al., 2014).

Several studies have indicated that $S$ nutrition plays a role in stress tolerance and defense mechanisms. For examples, thiol-containing compounds, especially reduced GSH, which is sensitive to oxidized environments, may be modulators of the stress response (Khan et al., 2009; Szalai et al., 2009). GSH has been shown to take part in the removal of reactive oxygen species (Rausch et al., 2007; Astolfi and Zuchi, 2013). Sulfur is an essential element in the formation of sulfhydryl (S-H) and disulfide bonds (S-S). These bonds are important for the stabilization of protein structures (Saito, 2000). In this context, the role of S nutrition in alleviating negative responses to salinity stress (Khan et al., 2009; Astolfi and Zuchi, 2013; Fatma et al., 2014) and iron deficiency (Zuchi et al., 2009; Muneer et al., 2014) have been widely reported.

Drought stress is one limiting factor to plant growth. In Korea, drought occurs predominantly from March to the early June, when the growth and development of most varieties of oilseed rape (winter type) actively progress. Oilseed rape is, therefore, often exposed to drought stress during the early stages of growth. Selection for physiologically efficient S-use cultivars may have value in breeding programs aimed at improving stress tolerance, grain yield, and quality. In this study, we hypothesized that cultivar variation in SUE under PEG-induced drought stress may be attributed to two components: (i) S-uptake efficiency (SUpE; S uptake per S supplied) and (ii) S-assimilation efficiency (SUaE; $S$ assimilated to amino acids and proteins per $S$ supplied), and that the genotype producing higher SUE is more tolerant to PEG-induced drought stress. To test this hypothesis, $\mathrm{S}$ uptake and the amount of $\mathrm{S}$ incorporated into amino acids and proteins were directly measured by a ${ }^{34} \mathrm{~S}$ tracing method. The responses to PEG-induced drought stress of parameters related to photosynthetic activity were also assessed in relation to SUE in two B. napus cultivars.

\section{MATERIALS AND METHODS}

\section{Plant Culture}

The surface-sterilized seeds of B. napus 'Mosa' and 'Saturnin' were sown into bed soil in a tray. At the three-leaf stage, seedlings were transferred to $2.5 \mathrm{~L}$ pots filled with hydroponic nutrient solution containing ( $\mathrm{mM}$ for the macro elements): $1.0 \mathrm{NH}_{4} \mathrm{NO}_{3}$; $0.4 \mathrm{KH}_{2} \mathrm{PO}_{4} ; 1.0 \mathrm{~K}_{2} \mathrm{SO}_{4} ; 0.5 \mathrm{~K}_{2} \mathrm{HPO}_{4} ; 3.0 \mathrm{CaCl}_{2} ; 0.5 \mathrm{MgSO}_{4} ; 0.15$ $\mathrm{K}_{2} \mathrm{HPO}_{4} ; 0.2 \mathrm{Fe}-\mathrm{Na}$ EDTA; and ( $\mu \mathrm{M}$ for the micro elements): 14 $\mathrm{H}_{3} \mathrm{BO}_{3} ; 5.0 \mathrm{MnSO}_{4} \cdot \mathrm{H}_{2} \mathrm{O}, 3.0 \mathrm{ZnSO}_{4} \cdot 7 \mathrm{H}_{2} \mathrm{O} ; 0.7 \mathrm{CuSO}_{4} \cdot 5 \mathrm{H}_{2} \mathrm{O}$; $0.7\left(\mathrm{NH}_{4}\right)_{6} \mathrm{Mo}_{7} \mathrm{O}_{24} ; 0.1 \mathrm{CoCl}_{2}$. Seedlings were then grown in a greenhouse. The nutrient solution was continuously aerated and renewed every 5 days. Natural light was supplemented by metal halide lamps, which generated c. $400 \mu \mathrm{mol}$ photons $\mathrm{m}^{-2} \mathrm{~s}^{-1}$ at the canopy height for $16 \mathrm{~h}$ per day.

\section{PEG-Induced Drought Stress and Isotope Labeling}

Eight-week-old plants were divided in two groups for the application of (PEG-6000). One group of experimental plants was supplied normal nutrient solution as a control. The other group was supplied 8\% PEG-6000 with normal nutrient solution for $72 \mathrm{~h}$. For the ${ }^{34} \mathrm{~S}$ feeding, $\mathrm{S}$ sources in hydroponic solution were replaced by ${ }^{34} \mathrm{~S}$ labeling solution containing $1.5 \mathrm{mM} \mathrm{K}_{2}{ }^{34} \mathrm{SO}_{4}$ with $1.0 \%{ }^{34} \mathrm{~S}$ atom excess.

\section{Measurements and Sampling}

Leaf water potential was measured as the petiole xylem-pressure potential using a pressure chamber (PMS Instrument Co. Corvallis, OR, USA). Photosynthesis rate, stomatal conductance and transpiration were measured in a greenhouse using a portable photosynthesis measurement system (LI-6400. LI-COR, Inc. Lincoln, NE, USA). One fully expanded mature leaf per plant was tagged with a small wire, and measurements were taken over $72 \mathrm{~h}$ of treatment. Measurement was done every day, $4 \mathrm{~h}$ after the beginning of the photoperiod on the same tagged leaf. The first sampling $(0 \mathrm{~h})$ was conducted just before the drought stress treatment (the beginning of ${ }^{34} \mathrm{SO}_{4}{ }^{2-}$ feeding) was applied at 10:00 h. Additional measurements were taken at 24, 48, and $72 \mathrm{~h}$ after treatment. The harvested plants were separated into leaves and roots. All plant samples were immediately frozen in liquid 
nitrogen after harvest, and then freeze-dried, weighed, ground, and stored in vacuum desiccators for further analysis.

\section{Chemical Fractionation and Isotope Analysis}

About $200 \mathrm{mg}$ of finely ground freeze-dried samples were extracted twice with $100 \mathrm{mM}$ sodium-phosphate buffer ( $\mathrm{pH}$ 7.5) at $4^{\circ} \mathrm{C}$. Proteins in the combined supernatant were precipitated with $80 \%(\mathrm{v} / \mathrm{v})$ acetone and centrifuged at $10,000 \times g$ at $4^{\circ} \mathrm{C}$ for $10 \mathrm{~min}$. The resulting pellets, which corresponded to NAS incorporated into protein fractions $\left({ }^{34} \mathrm{~S}\right.$-protein), were re-suspended in $0.5 \mathrm{~mL}$ of ultra-pure water. To measure NAS in sulfate $\left({ }^{34} \mathrm{~S}\right.$-sulfate), the aliquot obtained after protein precipitation was evaporated under vacuum at $4^{\circ} \mathrm{C}$ and centrifuged. The resulting supernatant was passed through an $\mathrm{H}^{+}$column (Dowex 50W $\times 8$ ). The $\mathrm{pH}$ of the solution collected from the $\mathrm{H}^{+}$column was adjusted to neutral $\mathrm{pH}$, and this solution was concentrated to a final volume of $0.5 \mathrm{~mL}$. The NAS incorporated into amino acids $\left({ }^{34} \mathrm{~S}\right.$-amino acids) was eluted from the Dowex $50 \mathrm{~W} \times 8$ column by using $25 \mathrm{~mL}$ of $0.5 \mathrm{M} \mathrm{HCl}$ and concentrated to $1 \mathrm{~mL}$. For the fractionated liquid samples, an appropriate sample volume (usually $0.1 \mathrm{~mL}$ ) was dropped into a tin capsule and freeze-dried before $S$ and ${ }^{34} S$ quantification. The NAS $\left({ }^{34} S\right.$ total S) was obtained from $5 \mathrm{mg}$ of freeze-dried powder samples.

The $\mathrm{S}$ content and ${ }^{34} \mathrm{~S}$ atom $\%$ of all fractions was determined by a continuous flow isotope mass spectrometer (IsoPrime, GV Instrument, Manchester, UK). The ${ }^{34} \mathrm{~S}$ abundances measured were converted to (RSA, i.e., \% of recently incorporated atoms relative to the total numbers of atoms in the sample) via the following equation (1):

$$
\begin{aligned}
\text { RSA }= & \left({ }^{34} \text { S atom } \% \text { measured }- \text { natural }^{34} \text { S atom \% }\right) / \\
& \left({ }^{34} \text { S atom } \% \text { of fed }{ }^{34} \mathrm{SO}_{4}{ }^{2-}-\text { natural }^{34} \text { S atom } \%\right) \times 100
\end{aligned}
$$

in which the natural ${ }^{34} \mathrm{~S}$ atom \% was adopted from the ${ }^{34} \mathrm{~S}$ atom $\%$ of non- ${ }^{34} \mathrm{~S}$-fed plants.

The amounts of NAS in the $\mathrm{S}$ containing compounds were calculated using equation (2):

$$
\mathrm{NAS}=(\mathrm{RSA} \times \mathrm{S} \text { content measured in a compound }) / 100 .
$$

\section{Determination of Sulfur Use Efficiency}

Sulfur use efficiency was assessed based on S uptake and S assimilation, respectively, in controls and PEG-induced drought stressed plants. SUE based on S uptake (SUpE) was calculated as the total amount of NAS $\left({ }^{34} \mathrm{~S}\right)$ per gram of $S$ provided in the nutrient solution during $72 \mathrm{~h}$ of the experiment, and expressed by $\mathrm{mg} S$ taken up $\mathrm{g}^{-1} \mathrm{~S}$ fed. SUE based on $\mathrm{S}$ assimilation (SUaE) was calculated as the total amount of $\mathrm{S}$ assimilated into amino acids and proteins $\left({ }^{34} \mathrm{~S}\right.$-amino acid $+{ }^{34} \mathrm{~S}$-protein) per gram of $S$ provided in the nutrient solution during $72 \mathrm{~h}$ of the experiment, and expressed by $\mathrm{mg} S$ assimilated $\mathrm{g}^{-1}$ $\mathrm{S}$ fed.

\section{SDS-PAGE and Quantification of Rubisco Protein}

Leaf samples were homogenized in chilled mortar with ice-cold extraction buffer containing $25 \mathrm{mM}$ Tris- $\mathrm{HCl}$ ( $\mathrm{pH} 7.8), 50 \mathrm{mM}$ $\mathrm{MgCl}_{2}, 2.5 \mathrm{mM}$ EDTA, and $1 \mathrm{mM}$ DTT. The homogenate was centrifuged at $10,000 \times g$ at $4^{\circ} \mathrm{C}$ for $10 \mathrm{~min}$ and the supernatant was applied to SDS polyacrylamide gel electrophoresis (SDSPAGE) for determination of Rubisco content. Twenty microgram proteins were separated in $1.0 \mathrm{~mm}$ thick gels containing $12.5 \%$ acrylamide (propenamide). The large subunit of Rubisco was detected by staining with Coomassie brilliant blue R-250. The individual band was extracted with formamide, and quantified by the Bradford dye binding assay using BSA as a standard (Makino et al., 1985).

\section{Statistical Analysis}

Analysis of variance (ANOVA) and Duncan's multiple range test were employed to compare the means of each treatment. Statistical significance was postulated at $P<0.05$. Statistical analysis of physiological and biochemical measurements was carried out using the software SAS 9.1.3.

\section{RESULTS}

\section{PEG-Induced Drought Stress Effects on Leaf Water Potential and Biomass in B. napus Cultivars}

Varietal differences and PEG-induced drought stress effects on $\Psi_{\mathrm{w}}$ were significant (Table 1). Drought stress decreased the $\Psi_{\mathrm{w}}$ gradually in both cultivars throughout the experiment, showing higher decrease in Mosa ( $-66.7 \%$ at $72 \mathrm{~h}$ after treatment) than in Saturnin (-56.9\%) (Table 2). The $\Psi_{\mathrm{w}}$ decreased in droughtstressed leaves, accompanied by the decrease in chlorophyll content in both cultivars. Varietal differences in biomass of drought-stressed plants was significance only in leaves (Table 1), and was overall higher in Saturnin in both controls and droughtstressed plants. A significant decrease in leaf biomass, caused by drought-stress, was observed only in Mosa at $72 \mathrm{~h}$ after treatment (Table 2).

\section{Amounts of Newly Absorbed S in Total S and in Sulfate Fraction}

Cultivar variation in NAS in total S $\left({ }^{34} \mathrm{~S}\right.$-total S) was significant in both leaves and roots (Table 1). Sum of ${ }^{34} \mathrm{~S}$-total $\mathrm{S}$ in leaves and roots $\left({ }^{34} \mathrm{~S}\right.$-total $\left.\mathrm{S}\right)$ at $72 \mathrm{~h}$ of treatment was $24.1 \mathrm{mg} \mathrm{S}$ plant ${ }^{-1}$ in Mosa and $28.7 \mathrm{mg} \mathrm{S}_{\text {plant }}{ }^{-1}$ in Saturnin for the non-stressed control plants (Table 3). PEG-induced drought stress decreased the amount of ${ }^{34} \mathrm{~S}$-total $\mathrm{S}$ in leaves and showed a significant cultivar difference, with a higher decrease in Mosa (-80.3\%) than in Saturnin $(-49.8 \%)$. A significant decrease in the amount of ${ }^{34}$ S-total $S$ in roots $(-40.6 \%)$ was apparent only in Mosa (Table 3).

The amount of NAS in sulfate fraction $\left({ }^{34} \mathrm{~S}\right.$-sulfate) in leaves showed cultivar difference in both controls and drought stressed plants (Table 3). PEG-induced drought stress decreased the 


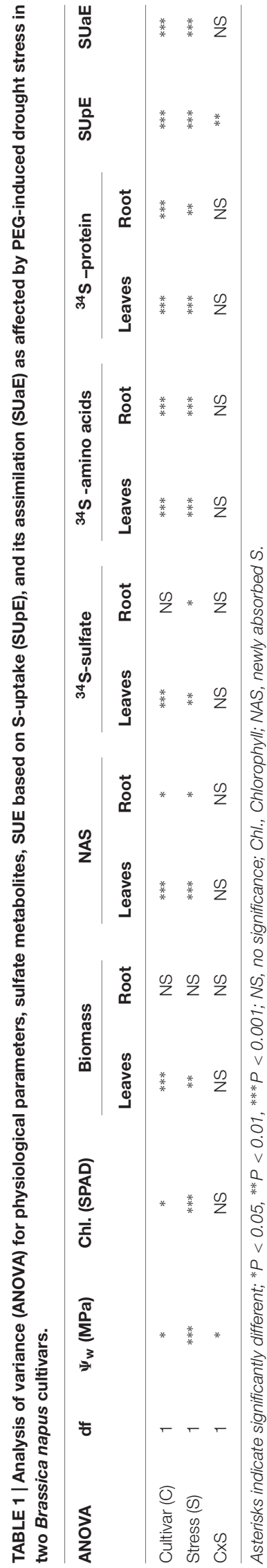

amount of ${ }^{34}$ S-sulfate in leaves by 28.9 and $17.5 \%$, respectively, in Mosa and Saturnin at $72 \mathrm{~h}$ after treatment, when compared to controls. However, PEG-induced drought stress overall increased the amount of ${ }^{34} \mathrm{~S}$-sulfate in roots, while cultivar variation was not significant (Tables 1 and $\mathbf{3}$ ).

\section{De novo Synthesis of Amino Acids and Proteins}

To investigate the assimilation of $\mathrm{SO}_{4}{ }^{2-}$ taken up during $72 \mathrm{~h}$ of PEG-induced drought stress, the amount of NAS incorporated into amino acids $\left({ }^{34} \mathrm{~S}\right.$-amino acids) or proteins $\left({ }^{34} \mathrm{~S}\right.$-proteins) were quantified. Cultivar variation and drought stress effects on the ${ }^{34}$ S-amino acids were significant $(P<0.001)$ (Table 1$)$. Overall, the amount of ${ }^{34} \mathrm{~S}$-amino acids was higher in Saturnin than in Mosa in both controls and drought-stressed plants for the entire course of the experiment (Figures 1A,B). PEG-induced drought stress decreased ${ }^{34} \mathrm{~S}$-amino acids significantly in both leaves and roots with varietal difference, showing 47.8 and $39.1 \%$ decreases in the leaves and roots of Mosa versus 37.0 and 35.7\% in Saturnin at $72 \mathrm{~h}$ after treatment, when compared to controls (Figures 1A,B).

Cultivar variation and drought stress effects for the ${ }^{34} \mathrm{~S}$ proteins were also highly significant $(P<0.001)$ (Table 1$)$. Overall, the amount of ${ }^{34} \mathrm{~S}$-proteins was higher than those assimilated into other fractions, particularly in the leaves (Figures 1C,D). Varietal difference in ${ }^{34} S$-protein was also observed in non-stressed controls (331.4 and $109.1 \mu \mathrm{g} \mathrm{S}$ plant $^{-1}$ in the leaves and roots of Mosa versus 526.0 and $153.9 \mu \mathrm{g}$ $S$ plant $^{-1}$, respectively, in Saturnin at $72 \mathrm{~h}$ after treatment). Drought stress decreased ${ }^{34} \mathrm{~S}$-proteins significantly in both leaves and roots. The decreases in ${ }^{34}$ S-proteins caused by drought stress was higher in leaves than in roots with cultivar variation, showing 42.3 and $37.7 \%$ decrease in the leaves and roots of Mosa versus 26.8 and $21.2 \%$, respectively, in Saturnin at $72 \mathrm{~h}$ after treatment when compared to controls (Figures 1C,D).

\section{Sulfur Use Efficiency Based on S Uptake and Its Assimilation Into Amino Acids and Proteins}

Cultivar variation in SUE based on S uptake (SUpE), calculated by dividing total NAS by the amount of $S$ supplied for $72 \mathrm{~h}$ of treatment, was significant (Table 1). SUpE in control plants was 200.4 and $238.0 \mathrm{mg} \mathrm{S}$ uptake $\mathrm{g}^{-1} \mathrm{~S}$ fed, respectively, in Mosa and Saturnin (Figure 2A). PEG-induced drought stress resulted in a reduction of SUpE with varietal difference, showing higher reduction in Mosa $(-66.7 \%)$ than in Saturnin $(-40.4 \%)$.

Sulfur use efficiency based on S assimilation (SUaE), calculated by dividing total amount of $S$ assimilated into amino acids and proteins by the amount of $S$ supplied for a given time, are presented in Figure 2B. Cultivar variation was significant $(P<0.001)$ for SUaE, with a range from $4.86 \mathrm{mg} \mathrm{S}$ assimilated $\mathrm{g}^{-1} \mathrm{~S}$ taken up (Mosa) to $7.71 \mathrm{mg}$ (Saturnin) in controls and from $2.80 \mathrm{mg} \mathrm{S}$ assimilated $\mathrm{g}^{-1} \mathrm{~S}$ taken up (Mosa) to $5.51 \mathrm{mg}$ (Saturnin) in PEG-induced drought stressed plants. The decrease in SUaE due to drought stress was largely higher in Mosa $(-42.3 \%)$ than in Saturnin $(-28.5 \%)$. 
TABLE 2 | Changes in $\Psi_{\mathrm{w}}$, total chlorophyll and biomass of B. napus 'Mosa' and 'Saturnin' under control or PEG-induced drought stress condition for $72 \mathrm{~h}$.

Physiological parameters/Treatment

\section{Leaf water potential ( $\left.\Psi_{\mathrm{w}}, \mathrm{MPa}\right)$}

Mosa

Saturnin

\section{Total chlorophyll content (mg g ${ }^{-1}$ FW)}

Mosa

Saturnin

Biomass (g plant ${ }^{-1}$ )

Leaves

Mosa

Saturnin

Roots

Mosa

Saturnin

control
PEG-stressed

control

PEG-stressed

\begin{tabular}{llll}
\multicolumn{7}{c}{ Hours after treatment } \\
\hline 0 & 24 & 48 & 72
\end{tabular}

$$
\begin{array}{ll}
-0.41 \pm 0.04 a & -0.42 \pm 0.05 a \\
-0.45 \pm 0.07 a & -0.70 \pm 0.09 b \\
& -0.44 \pm 0.06 a \\
& -0.68 \pm 0.13 b
\end{array}
$$

$$
\begin{aligned}
& -0.42 \pm 0.05 a \\
& -0.95 \pm 0.10 b \\
& -0.42 \pm 0.03 a \\
& -0.86 \pm 0.08 b
\end{aligned}
$$

$-0.42 \pm 0.04 a$

$-1.26 \pm 0.09 c$

$-0.44 \pm 0.06 \mathrm{a}$

$-1.02 \pm 0.11 b$

$\begin{array}{lcccc}\text { control } & 2.85 \pm 0.07 \mathrm{~b} & 3.15 \pm 0.28 \mathrm{ab} & 3.17 \pm 0.61 \mathrm{a} & 2.99 \pm 0.39 \mathrm{a} \\ \text { PEG-stressed } & & 2.55 \pm 0.32 \mathrm{c} & 1.44 \pm 0.11 \mathrm{~b} & 0.88 \pm 0.14 \mathrm{c} \\ \text { control } & 3.28 \pm 0.17 \mathrm{a} & 3.28 \pm 0.12 \mathrm{a} & 3.47 \pm 0.04 \mathrm{a} & 3.38 \pm 0.31 \mathrm{a} \\ \text { PEG-stressed } & & 2.71 \pm 0.04 \mathrm{bc} & 1.92 \pm 0.09 \mathrm{~b} & 1.36 \pm 0.07 \mathrm{~b}\end{array}$

control

$9.78 \pm 0.65 b$
$9.32 \pm 0.21 b$
$9.21 \pm 0.56 b$
$11.78 \pm 0.54 a$

$11.87 \pm 0.33 a$

$11.68 \pm 0.95 a$

$9.44 \pm 0.34 b c$

$8.57 \pm 0.21 \mathrm{c}$

$11.84 \pm 1.12 \mathrm{a}$

$10.79 \pm 0.81 a b$

$4.82 \pm 0.34 a$

$4.75 \pm 0.08 \mathrm{a}$

PEG-stressed

control

$4.79 \pm 0.25 b$

$5.66 \pm 0.45 a$

$5.63 \pm 0.36 a$

$5.65 \pm 0.48 a$

$\begin{array}{ll}5.28 \pm 0.40 a & 5.05 \pm 0.12 a \\ 5.25 \pm 0.45 a & 5.45 \pm 0.37 a \\ 5.88 \pm 0.57 a & 5.72 \pm 0.52 a \\ 5.65 \pm 0.51 a & 5.78 \pm 0.42 a\end{array}$

$5.28 \pm 0.40 a$

\begin{tabular}{|c|c|c|c|c|c|}
\hline \multirow[t]{2}{*}{ Physiological parameters/Treatment } & & \multicolumn{4}{|c|}{ Hours after treatment } \\
\hline & & 0 & 24 & 48 & 72 \\
\hline \multicolumn{6}{|c|}{ Newly absorbed S $\left({ }^{34}\right.$ S-total S, mg plant $\left.{ }^{-1}\right)$} \\
\hline \multicolumn{6}{|l|}{ Leaves } \\
\hline \multirow[t]{2}{*}{ Mosa } & control & - & $4.74 \pm 0.65 b$ & $9.80 \pm 1.03 b$ & $13.99 \pm 0.87 b$ \\
\hline & PEG-stressed & & $0.98 \pm 0.14 c$ & $1.89 \pm 0.26 \mathrm{~d}$ & $2.75 \pm 0.34 d$ \\
\hline \multirow[t]{2}{*}{ Saturnin } & control & - & $7.73 \pm 0.81 a$ & $15.06 \pm 0.55 a$ & $21.98 \pm 0.55 a$ \\
\hline & PEG-stressed & & $3.69 \pm 0.44 b$ & $7.31 \pm 0.36 c$ & $11.03 \pm 0.40 c$ \\
\hline \multicolumn{6}{|l|}{ Roots } \\
\hline \multirow[t]{2}{*}{ Mosa } & control & - & $2.94 \pm 0.23 a$ & $6.85 \pm 0.25 a$ & $10.14 \pm 0.35 a$ \\
\hline & PEG-stressed & & $1.88 \pm 0.15 b$ & $3.78 \pm 0.25 b$ & $5.96 \pm 0.28 b$ \\
\hline \multirow[t]{2}{*}{ Saturnin } & control & - & $2.43 \pm 0.40 a b$ & $4.39 \pm 0.68 b$ & $6.67 \pm 0.57 b$ \\
\hline & PEG-stressed & & $1.92 \pm 0.15 b$ & $3.67 \pm 0.34 b$ & $5.90 \pm 0.53 b$ \\
\hline \multicolumn{6}{|c|}{ Non-assimilated sulfate $\left({ }^{34} \mathrm{~S}\right.$-sulfate, $\mu$ g plant $\left.{ }^{1}\right)$} \\
\hline \multicolumn{6}{|l|}{ Leaves } \\
\hline \multirow[t]{2}{*}{ Mosa } & control & - & $63.8 \pm 2.5 \mathrm{ab}$ & $130.5 \pm 2.9 \mathrm{bc}$ & $200.1 \pm 10.5 b$ \\
\hline & PEG-stressed & & $57.3 \pm 9.8 b$ & $105.4 \pm 15.8 c$ & $142.2 \pm 20.6 c$ \\
\hline \multirow[t]{2}{*}{ Saturnin } & control & - & $83.2 \pm 3.5 \mathrm{a}$ & $172.5 \pm 9.1 \mathrm{a}$ & $268.6 \pm 11.0 \mathrm{a}$ \\
\hline & PEG-stressed & & $76.4 \pm 14.8 \mathrm{ab}$ & $148.6 \pm 16.5 \mathrm{ab}$ & $221.7 \pm 25.2 b$ \\
\hline \multicolumn{6}{|l|}{ Roots } \\
\hline \multirow[t]{2}{*}{ Mosa } & control & - & $58.2 \pm 4.3 a$ & $130.5 \pm 20.4 \mathrm{bc}$ & $195.4 \pm 27.9 a b$ \\
\hline & PEG-stressed & & $67.1 \pm 10.9 a$ & $161.5 \pm 14.0 \mathrm{a}$ & $250.0 \pm 17.6 a$ \\
\hline \multirow[t]{2}{*}{ Saturnin } & control & - & $54.6 \pm 6.3 a$ & $108.5 \pm 14.9 c$ & $162.6 \pm 20.7 b$ \\
\hline & PEG-stressed & & $62.3 \pm 12.5 a$ & $130.0 \pm 23.7 \mathrm{bc}$ & $202.1 \pm 32.0 \mathrm{ab}$ \\
\hline
\end{tabular}

$9.43 \pm 0.41 b$

$7.56 \pm 0.38 c$

$12.17 \pm 0.57 a$

$11.00 \pm 0.74 a$

PEG-stressed

Values are means $\pm S D$ of three replicates. Values in a vertical column followed by different letters are significantly different at $P<0.05$ according to Duncan's multiple range test.

TABLE 3 | Changes in amount of NAS $\left({ }^{34}\right.$ S-total S) and non-assimilated sulfate $\left({ }^{34}\right.$ S-sulfate) in leaves and roots of $B$. napus 'Mosa' and 'Saturnin' under control or PEG-induced drought stress condition for $72 \mathrm{~h}$.

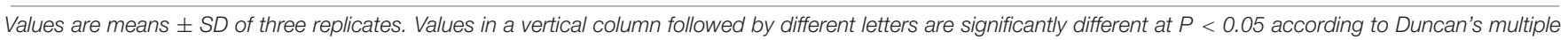
range test. 

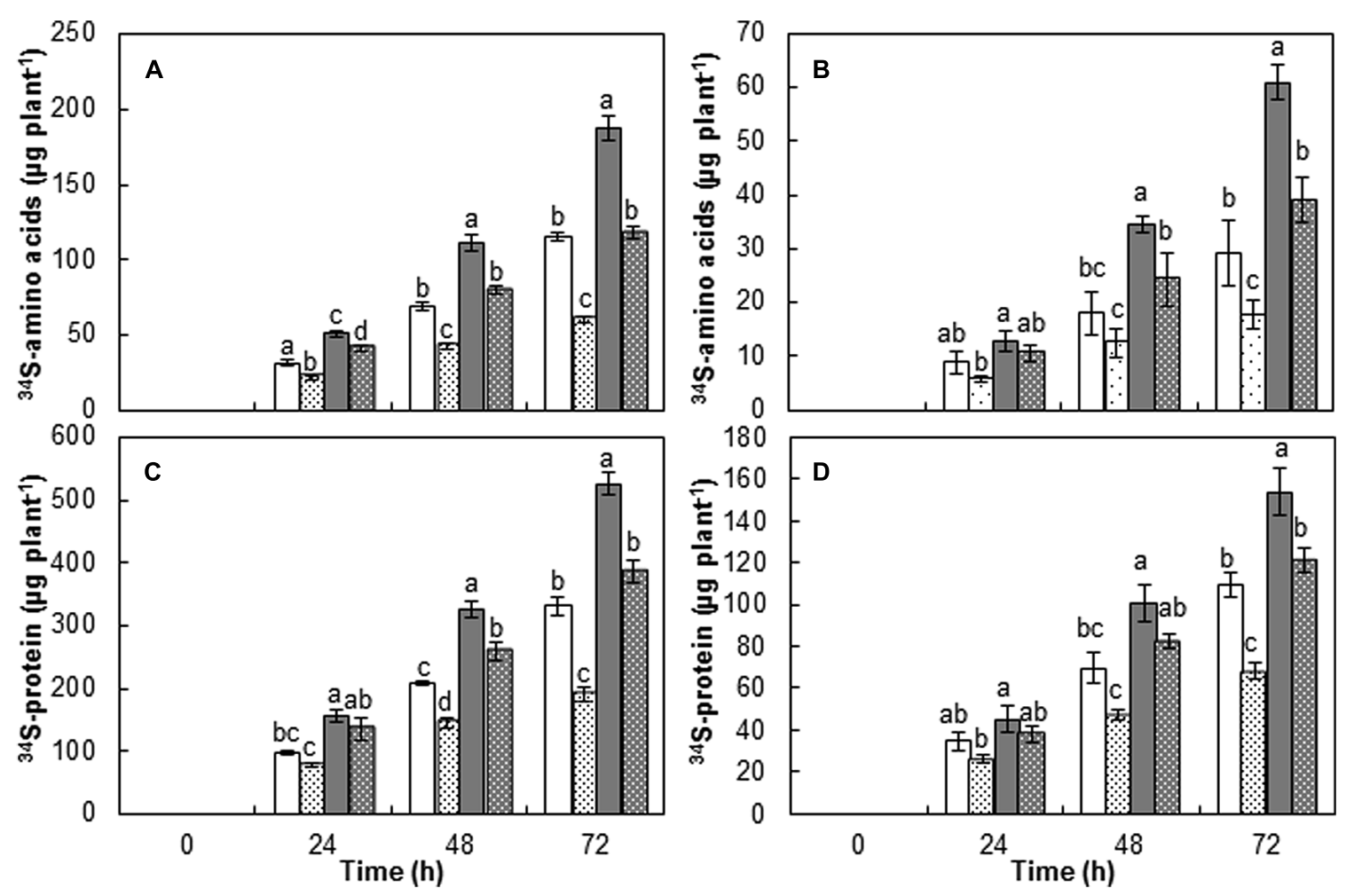

FIGURE 1 | Amount of S assimilated into amino acids and proteins in leaves (A,C) and roots (B,D) of cultivars Mosa (white bar) or Saturnin (dark gray bar) under control (non-dotted bar) or PEG-induced drought stress (dotted bar) conditions for $\mathbf{7 2} \mathbf{h}$. Data are presented as mean \pm SE for $n=3$. Means denoted by the different letter are significantly different at $P<0.05$ according to the Duncan's multiple range test.

\section{Rubisco Protein Content and Photosynthetic Activity}

Rubisco protein patterns showed considerable varietal difference in PEG-induced drought stressed plants (Figure 3A). PEGinduced drought stress degraded the prominently large subunits of Rubisco in the low intensity band and slightly degraded the smaller subunits in Mosa (Figure 3A Lane 2-3), while much less change was observed in Saturnin (Figure 3A Lane 4-5). The decrease in Rubisco protein due to drought stress was estimated as $75.6 \%$ in Mosa and $51.1 \%$ in Saturnin at $72 \mathrm{~h}$ after treatment (Figure 3B).

Polyethylene glycol-induced drought stress decreased the net photosynthesis rate significantly with varietal difference, representing 74.6 and $58.5 \%$ decrease in Mosa and Saturnin, respectively at $72 \mathrm{~h}$ after treatment when compared to controls (Figure 4A). Varietal difference and drought stress effects on stomatal conductance and transpiration were similar to that of the net photosynthesis rate (Figures $4 \mathrm{~B}, \mathrm{C}$ ).

\section{DISCUSSION}

The present data allow us to interpret firstly the physiological basis of genetic variation in SUE under PEG-induced drought stress. Secondly, the physiological significance of SUE in drought stress tolerance, with a particular focus on photosynthetic activity, will be discussed for two $B$. napus cultivars with different SUE. Following PEG application for $72 \mathrm{~h}$, droughtstress occurred in both $B$. napus cultivars as shown by $\Psi_{\mathrm{w}}$ values (Table 2). The final $\Psi_{\mathrm{w}}$ in PEG-induced drought stressed plants reached a minimum value of -1.26 and $-1.02 \mathrm{MPa}$, respectively, in Mosa and Saturnin. These values were slightly lower than that $(-0.87 \mathrm{MPa})$ recorded over eight B. napus cultivars exposed to water-deficit stress for 7 days (Lee et al., 2015), indicating that PEG provokes drought stress more quickly than water deficiency treatment. These values were, however, higher than that $(-1.41 \mathrm{MPa})$ recorded for four annual clover species exposed to water-stress (Iannucci et al., 2002). The $\Psi_{\mathrm{w}}$ has often been used as the criterion for the degree of stress in many studies of stress physiology because the decrease in $\Psi_{\mathrm{w}}$, caused by increase in hydraulic or osmotic stress, is responsible for decrease in photosynthetic $\mathrm{CO}_{2}$ assimilation rates (Costa Franca et al., 2000), nitrogen assimilation (Kim et al., 2004; Lee et al., 2009), and cell extension processes (Singh et al., 2000).

As expected, PEG-induced drought stress resulted in a reduction of $S$ uptake, estimated by newly absorbed ${ }^{34} \mathrm{~S}$ amount accumulated during treatment, with varietal difference (Tables 1 and 3). The rate of decrease in total amount of $S$ uptake caused by drought stress was generally less in Saturnin $(-40.9 \%)$ than in Mosa $(-63.9 \%)$, indicating that Saturnin is able to more efficiently absorb S under drought-stressed conditions. 


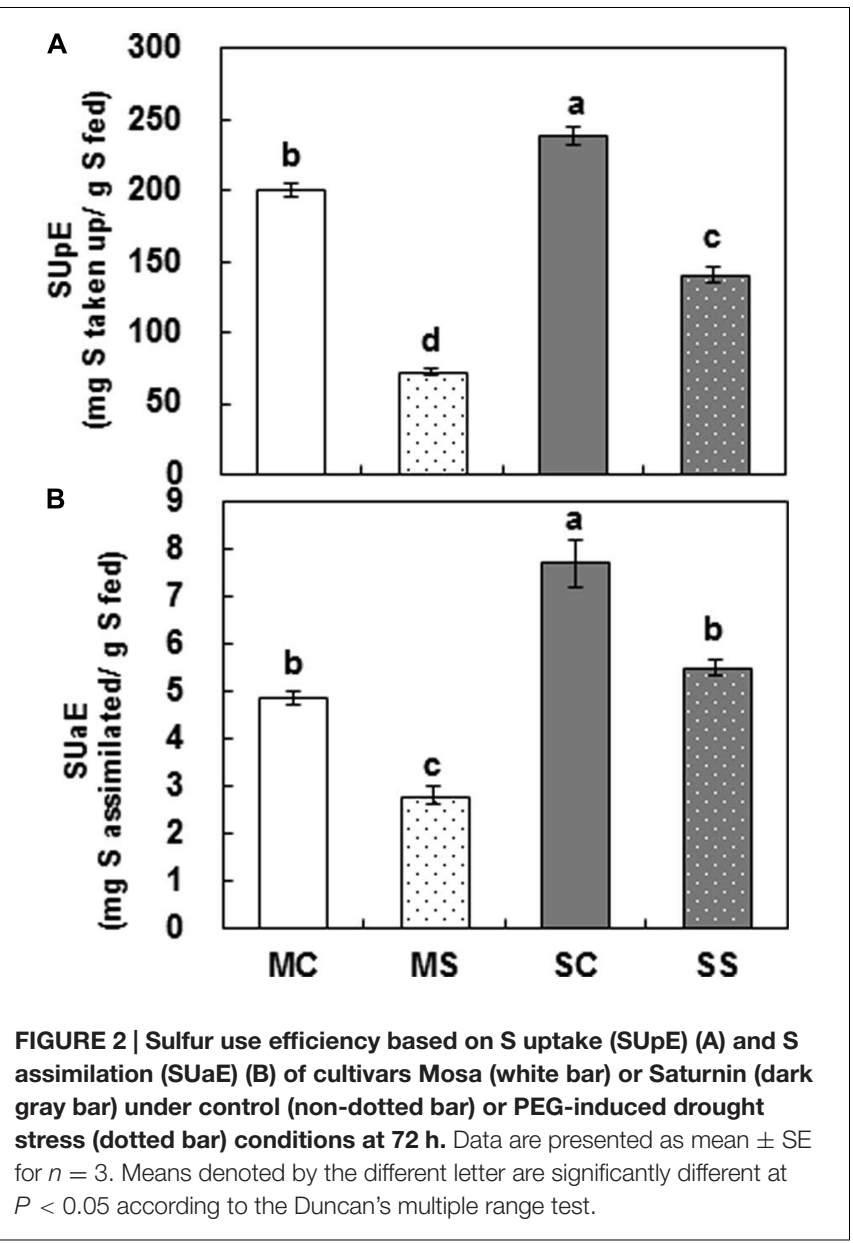

Similarly, Saturnin was estimated to have the highest capacity of $\mathrm{N}$ acquisition of eight $B$. napus cultivars exposed to a water deficit stressed condition (Lee et al., 2015). The proportion of NAS distributed to leaves under drought-stressed conditions was also generally higher in Saturnin (76.7\% of total S newly absorbed) than in Mosa (58.0\%). These results suggest that PEG-induced drought stress restricts the translocation of newly absorbed $\mathrm{SO}_{4}{ }^{2-}$ to leaves, as a consequence of low $\mathrm{SO}_{4}{ }^{2-}$ absorption. Low absorption of $\mathrm{NO}_{3}{ }^{-}$and decreased translocation into leaves were observed in white clover (Lee et al., 2009) and B. napus species with low $\mathrm{N}$ use efficiency (Lee et al., 2015) under water deficiency.

Polyethylene glycol-induced drought stress significantly decreased the amount of $\mathrm{S}$ assimilated into amino acids $\left({ }^{34} \mathrm{~S}\right.$-amino acids) and proteins $\left({ }^{34} \mathrm{~S}\right.$-proteins). The rate of decrease in ${ }^{34} \mathrm{~S}$-proteins was much higher in leaves $(-32.8 \%$ on average for the two cultivars) than in roots $(-28.1 \%)$. Similarly, we recently reported that the inhibition of $\mathrm{N}$ assimilation into amino acids and proteins due to water-deficit stress occurred more severely in leaves than in roots (Lee et al., 2015). These results indicate that protein synthesis in leaves may be a major sink for $\mathrm{S}$ and $\mathrm{N}$ assimilation and is likely to be more inhibited by water stress (Kim et al., 2004) and nutrient deficiency (Lee et al., 2013, 2014). Decreases

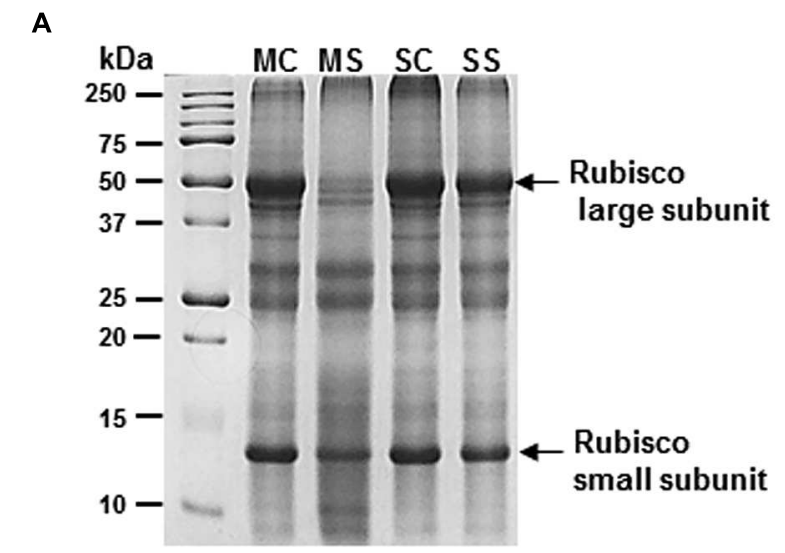

B

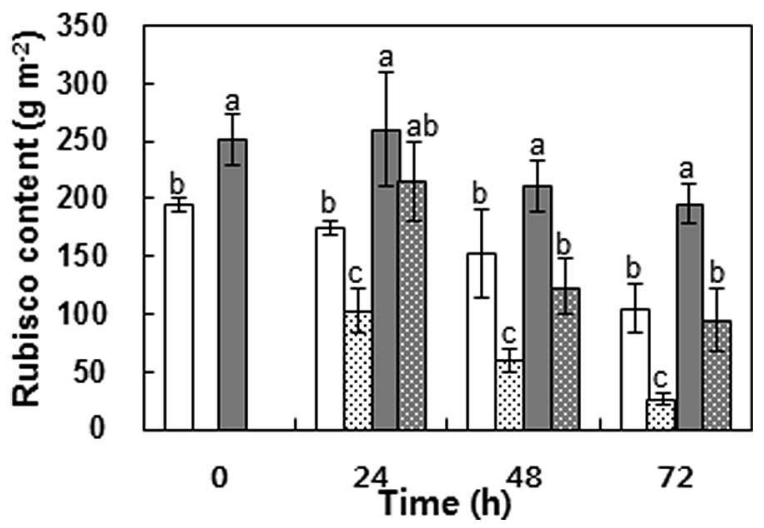

FIGURE 3 | Leaf protein pattern after SDS-PAGE of cultivars Mosa (M) and Saturnin (S) at $72 \mathrm{~h}$ after control (MC or SC) and PEG-induced drought stress (MS or SS) treatment (A). Changes in Rubisco protein content (B) of leaves of Mosa (white bar) or Saturnin (dark gray bar) under control (non-dotted bar) or PEG-induced drought stress (dotted bar) conditions for $72 \mathrm{~h}$. Data are presented as mean \pm SE for $n=3$. Means denoted by the different letter are significantly different at $P<0.05$ according to the Duncan's multiple range test.

in sulfate uptake, translocation and further assimilation in drought stressed plants (Table 1; Figure 1) are likely to be driven by low sulfur demand for protein synthesis (De Kok et al., 2002; Anderson and Fitzgerald, 2003). Significant cultivar variation in the impacts of PEG-induced drought stress on de novo protein synthesis in leaves was found, with higher rates of decrease of ${ }^{34}$ S-proteins in Mosa $(-42.3 \%)$ than in Saturnin $(-26.8 \%)$. A similar finding was made for roots. These results indicate that the inhibition of protein incorporation derived from newly absorbed $\mathrm{SO}_{4}{ }^{2-}$, caused by drought stress, occurs much less often in cultivars with high S uptake (e.g., Saturnin). This suggests that newly absorbed $\mathrm{SO}_{4}{ }^{2-}$ is preferentially assimilated into proteins, rather than being stored in vacuoles, so that the capacity of $S$ acquisition is an essential determinant for SUE under drought stress.

For assessing the genotypic variation in tolerance to nutrient deficiency, most studies have focused on nitrogen-use efficiency 


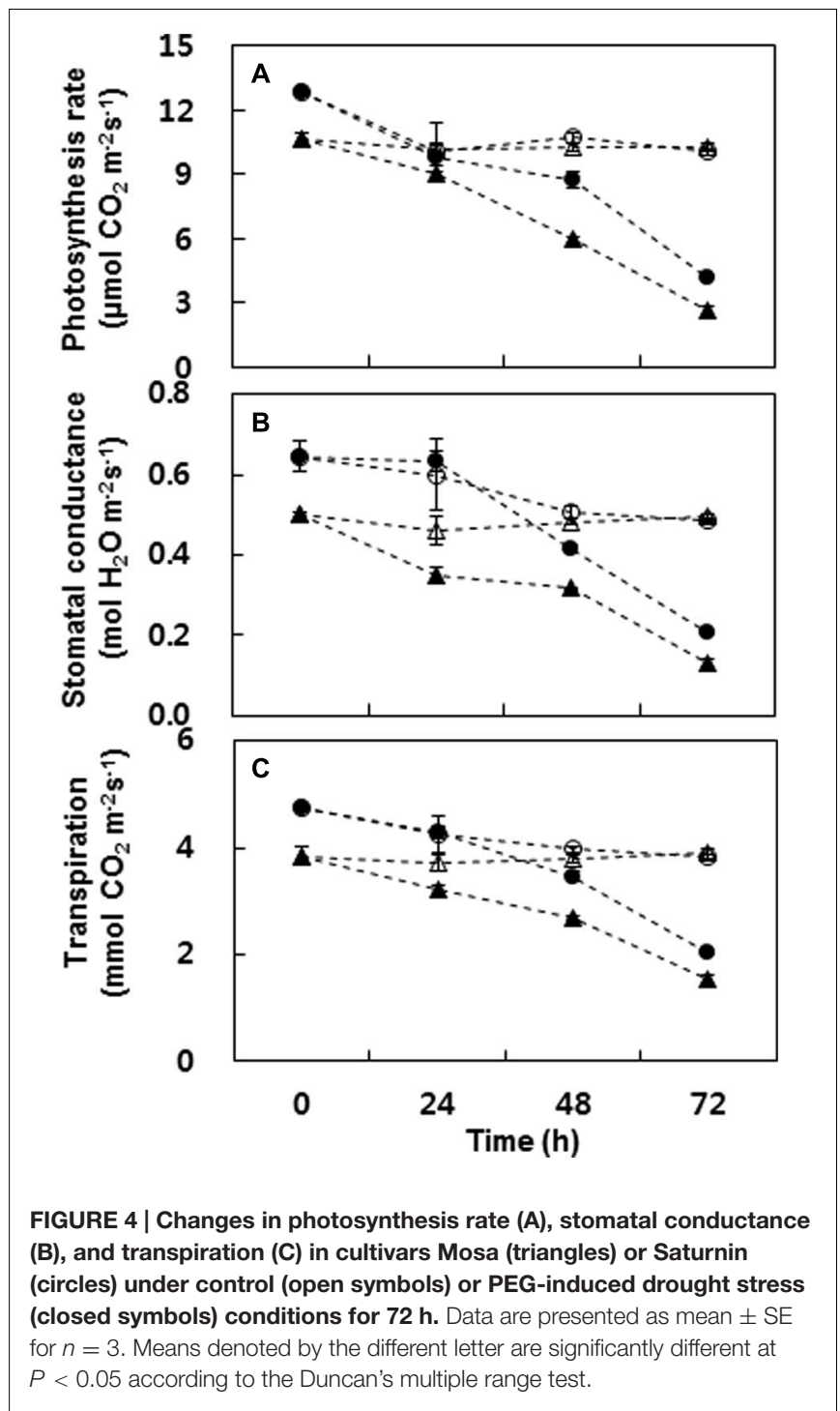

(Ahmad et al., 2005, 2008; Berry et al., 2010), rather than on SUE. The physiological basis of varietal differences has been mostly interpreted by the relationships between growth and yield characteristics. In this study, cultivar variation in SUE, based on S uptake (SUpE) and S assimilation (SUaE), was assessed using ${ }^{34} \mathrm{~S}$ tracing. This data, to the best of our knowledge, is the first to directly quantify NAS and its assimilation into amino acids and proteins in response to PEG-induced drought stress. Cultivar variation was significant for SUpE, expressed as $\mathrm{mg} S$ taken up per $\mathrm{g} S$, supplied under PEG-induced drought stress treatment (Figure 2A). The SUpE of Saturnin was 1.2 times higher in the control and 1.9 times higher in drought stressed plants than those of Mosa. Similarly, SUE based on $\mathrm{S}$ assimilation (SUaE), expressed as $\mathrm{mg} \mathrm{S}$ assimilated per g $\mathrm{S}$ supplied, was also significantly higher in Saturnin in both controls and drought stressed plants (Figure 2B). In addition, the decreases in SUpE and SUaE caused by PEG-induced drought stress were smaller in Saturnin that those in Mosa. These results indicate that Saturnin is a genotype with a higher SUE compared to Mosa. In a recent study on nitrogen use efficiency based on $\mathrm{N}$ uptake (NUpE) and $\mathrm{N}$ assimilation (NUaE), Saturnin was also identified as one of the most $\mathrm{N}$-use efficient genotypes of eight B. napus cultivars (Lee et al., 2015). This indicates that cultivar variation in SUE is likely to be similar to that of NUE. For B. napus, studies carried out under controlled greenhouse (Balint and Rengel, 2008; Dubousset et al., 2010) or field conditions (Schnug et al., 1993; Fismes et al., 2000) have shown that $\mathrm{S}$ nutrition affects the $\mathrm{N}$-use efficiency and vice versa.

In this study, PEG-induced drought stress resulted in a gradual decrease in photosynthetic rate, along with a reduction in stomatal conductance and transpiration (Figure 4). These results are in accordance with previous results received in experiments with white clover cultivated under water deficiency (Lee et al., 2009). The reduction in the photosynthesis rate results from stomatal closure, which is associated with increased concentrations of ions and other solutes in the cells and the associated decrease in the osmotic potential (Cornic, 1994). Stomatal closure decreases available internal $\mathrm{CO}_{2}$ and restricts water loss through transpiration (Chaves, 1991; Tezara et al., 1999). In this study, PEG-induced drought stress degraded Rubisco proteins in both the $B$. napus cultivars examined (Figure 3). The inhibition of photosynthetic activity and Rubisco degradation was less significant in Saturnin, which showed a higher efficiency in $S$ uptake and $S$ assimilation (Figures 3 and 4). This suggests that a good SUE has the potential to alleviate negative responses caused by drought stress on photosynthetic activity. Indeed, significant correlation of SUpE or SUaE with $\Psi_{\mathrm{w}}$ affected by PEG-induced drought stress was found (Figures 5A,D). Positive relationships between SUpE or SUaE with net photosynthesis rate and Rubisco content, recorded at $72 \mathrm{~h}$ after treatment for the two $B$. napus cultivars examined in this study, were also significant (Figures 5B,C,E,F). Reduced photosynthesis under S-deficient conditions has been widely observed in various plant species (Astolfi et al., 2012; Fatma et al., 2014; Muneer et al., 2014). S-deficiency has an early effect on $\mathrm{CO}_{2}$ assimilation and on Rubisco activity and protein abundance, thereby inducing chlorosis (Gilbert et al., 1997). The lack of Rubisco synthesis and chlorosis reflects a general inhibition of de novo synthesis of photosynthetic apparatus (Hawkesford, 2000). However, in B. juncea and B. campestris, high S-fertilization increases chlorophyll, Rubisco, and protein contents, and leads to better photosynthetic capacity, compared to the plants grown without S (Ahmad and Abdin, 2000; Fatma et al., 2014). It has also been reported that surplus or sufficient S-supply favors the formation of Fe-S clusters in the photosynthetic apparatus and electron transport system, alleviating the photosynthetic activity inhibited by salt stress (Resurreccion et al., 2002; Nazar et al., 2011) or Fe deficiency (Astolfi et al., 2012; Muneer et al., 2014). Application of exogenous ally isothiocyanate, which is one of the products of hydrolysis of glucosinolates, induced stomatal closure leading to the elevation of guard cell cytosolic $\mathrm{Ca}^{2+}$ to avoid water loss (Khokon et al., 2011). Recently it was 


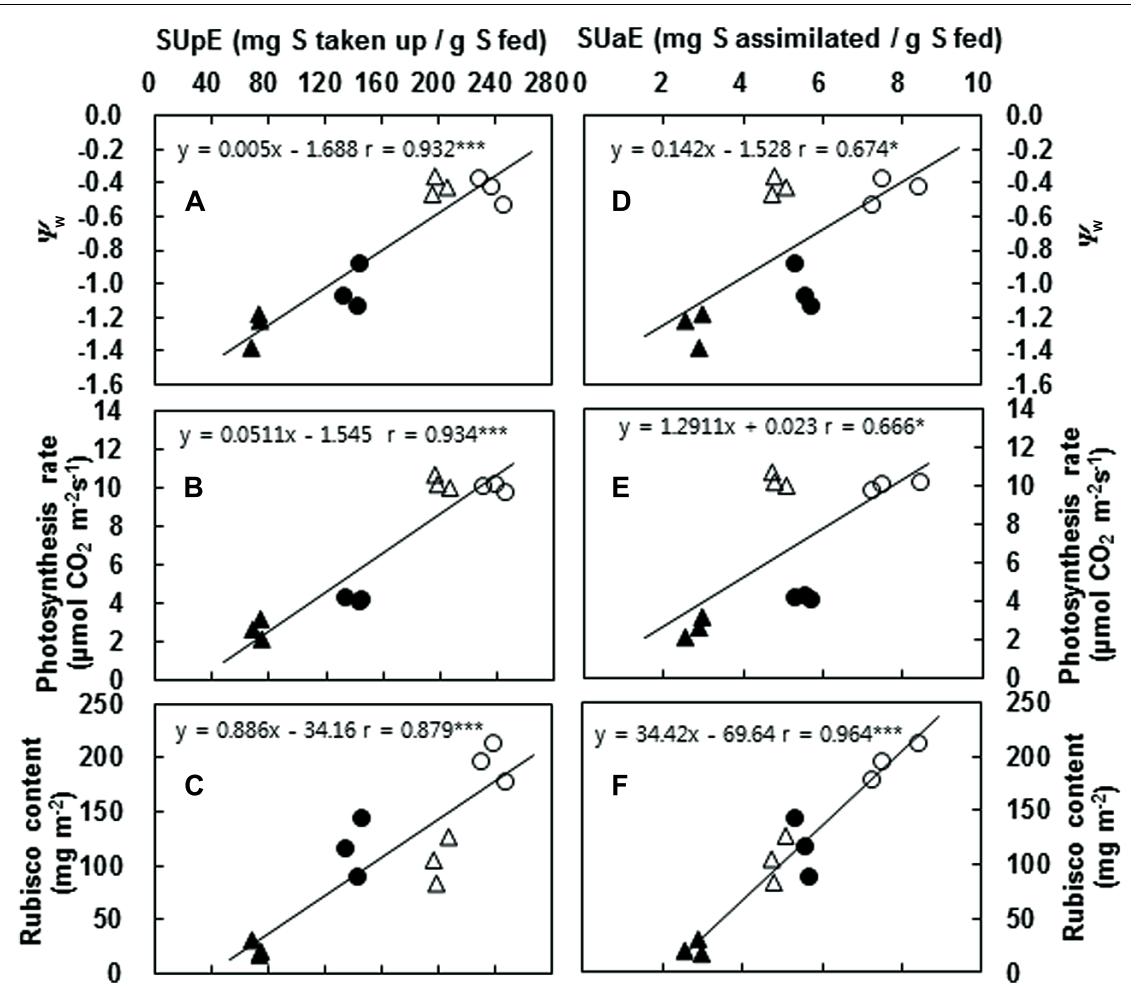

FIGURE 5 | Correlation of SUpE or SUaE with $\Psi_{w}(A, D)$, photosynthesis (B,E), Rubisco content (C,F) with the values measured at $72 \mathrm{~h}$ after control (open symbol) and PEG-induced drought stress (closed symbol) treatment in cultivars Mosa (triangles) or Saturnin (circles). Significant levels of the linear correlation coefficient were denoted by ${ }^{*} P<0.05$, ${ }^{* *} P<0.01$ and ${ }^{* * *} P<0.001$.

shown that an excess S supply improved photosynthesis under salt stress condition (Fatma et al., 2014). These positive effects of surplus S-supplementation may be explained by increased S-availability for the formation of S-containing compounds such as amino acids (cysteine and methionine for assembly of new proteins), antioxidant peptides (GSH for protection against oxidative damage), and sulfhydryl (S-H) and disulfide (S-S) bonds that are important for the stabilization of protein structure (Saito, 2000), and S-Fe clusters that function in vital processes such as respiration, photosynthesis, and sulfur and nitrogen metabolism (Balk and Pilon, 2011). These results suggest that SUpE is a determinant for total S-availability, which has significant roles in alleviating negative responses of photosynthetic activity to drought stress, and is a preliminary factor for SUaE. Indeed, the data presented here shows that the inhibition of photosynthetic activity (including Rubisco degradation) is much less apparent in the cultivar with higher SUpE and SUaE (Saturnin), and that this cultivar can be identified as a genotype more tolerant to PEGinduced drought stress, compared to the inefficient SUE cultivar (Mosa).

\section{CONCLUSION}

This study suggests that SUE based on S uptake (SUpE) and $S$ assimilation (SUaE) displays significant role in alleviating negative responses to drought stress on photosynthetic activity. Thus, an improved SUE is certainly a desired feature for the management of crops against drought stress and for breeding programs with the target to improve the stress tolerance of plants.

\section{AUTHOR CONTRIBUTIONS}

$\mathrm{B}-\mathrm{RL}$ and T-HK designed the experiment and wrote the manuscript. B-RL carried out the experiment. $\mathrm{T}-\mathrm{HK}, \mathrm{J}-\mathrm{CA}$, and $\mathrm{AO}$ participated in data interpretation and critical reading of the manuscript. $\mathrm{RZ}$ has been involved in revising the article for important intellectual content.

\section{FUNDING}

This work was supported by the National Research Foundation of Korea (NRF) grant (NRF-2013R1A2A2A01014202).

\section{ACKNOWLEDGMENT}

We gratefully thank Marie-Paule Bataillé for conducting isotopic analysis. 


\section{REFERENCES}

Abdallah, M., Dubousset, L., Meuriot, F., Etienne, P., Avice, J. C., and Ourry, A. (2010). Effect of mineral Sulphur availability on nitrogen and Sulphur uptake and remobilization during the vegetative growth of Brasscia napus L. J. Exp. Bot. 61, 2635-2646. doi: 10.1093/jxb/erq096

Aghajanzadeh, T., Hawkesford, M. J., and De Kok, L. J. (2014). The significance of glucosinolates for sulfur storage in Brassicaceae seedlings. Front. Plant Sci. 5:704. doi: 10.3389/fpls.2014.00704

Ahmad, A., and Abdin, M. Z. (2000). Effect of sulphur application on lipid, RNA and fatty acid content in developing seeds of rapeseed (Brassica campe L.). Plant Sci. 150, 71-76. doi: 10.1016/S0168-9452(99)00167-3

Ahmad, A., Hussain, A., Iqbal, S., and Husnain, Z. (2005). "Growth, radiation use efficiency and paddy yield of fine rice (Super basmati) as affected by sowing date and split nitrogen application," in Proceedings of the International Seminar on Rice Crop, (Lahore Pak: RRI), 315-321.

Ahmad, A., Khan, I., Abrol, Y. P., and Iqbal, M. (2008). Genotypic variation of nitrogen-use efficiency in Indian mustard. Environ. Pollut. 154, 462-466. doi: 10.1016/j.envpol.2007.10.007

Anderson, J. W., and Fitzgerald, M. A. (2003). "Sulphur distribution and redistribution," in Sulphur in Plants, eds Y. P. Abrol and A. Ahmad (Dordrecht: Kluwer Academic), 113-134.

Astolfi, S., and Zuchi, S. (2013). Adequate S supply protects barley plants from adverse effects of salinity stress by increasing thiol contents. Acta Physiol. Plant. 35, 175-181. doi: 10.1007/s11738-012-1060-5

Astolfi, S., Zuchi, S., Neumann, G., Cesco, S., di Toppi, L., and Pinton, R. (2012). Response of barley plants to Fe deficiency and Cd contamination as affected by S starvation. J. Exp. Bot. 633, 1241-1250. doi: 10.1093/jxb/ err344

Balint, T., and Rengel, Z. (2008). Nitrogen efficiency of canola genotypes varies between vegetative stage and grain maturity. Euphytica 164, 421-432. doi: 10.1007/s10681-008-9693-6

Balk, J., and Pilon, M. (2011). Ancient and essential, the assembly of iron-sulfur clusters in plants. Trends Plant Sci. 16, 218-226. doi: 10.1016/j.tplants.2010.12.006

Berry, P. M., Spink, J., Foulkes, M. J., and White, P. J. (2010). The physiological basis of genotypic differences in nitrogen use efficiency in oilseed rape (Brassica napus L.). Field Crops Res. 119, 365-373. doi: 10.1016/j.fcr.2010. 08.004

Blake-Kalff, M., Zhao, J., Hawkesford, M., and McGrath, S. (2001). Using plant analysis to predict yield losses by sulphur deficiency. Ann. Appl. Biol. 138, 123-127. doi: 10.1111/j.1744-7348.2001.tb00093.x

Castro, A., Aires, A., Rosa, E., Bloem, E., and Stulen, I. (2004). Distribution of glucosinolates in Brassica oleracea cultivars. Phyton (B Aires) 44, 133-143.

Chaves, M. M. (1991). Effects of water deficits on carbon assimilation. J. Exp. Bot. 42, 1-16. doi: 10.1093/jxb/42.1.1

Cornic, G. (1994). "Drought stress and high light effects on leaf photosynthesis," in Photoinhibition of Photosynthesis, eds N. R. Baker and J. R. Bowyer (Oxford: Bios Scientific Publishers), 297-313.

Costa Franca, M. G., Pham Thi, A. T., Pimentel, C., Pereyra Rossiello, R. O., ZuilyFodil, Y., and Laffray, D. (2000). Differences in growth and water relations among Phaseolus vulgaris cultivars response to induced drought stress. Environ. Exp. Bot. 43, 227-237. doi: 10.1016/S0098-8472(99)00060-X

De Kok, L. J., Castro, A., Durenkamp, M., Stuiver, C. E. E., Westerman, S., Yang, L., et al. (2002). "Sulphur in plant physiology," in Proceedings No. 500. (New York: International Fertiliser Society), 1-26.

Dubousset, L., Etienne, P., and Avice, J. C. (2010). Is the remobilization of S and $\mathrm{N}$ reserves for seed filling of winter oilseed rape modulated by sulphate restrictions occurring at different growth stages? J. Exp. Bot. 61, 4313-4324. doi: 10.1093/jxb/erq233

Fatma, M., Asgher, M., Masood, A., and Khan, N. A. (2014). Excess sulfur supplementation improves photosynthesis and growth in mustard under salt stress through increased production of glutathione. Environ. Exp. Bot. 107, 55-63. doi: 10.1080/15592324.2014.1003751

Fismes, J., Vong, P. C., Guckert, A., and Frossard, E. (2000). Influence of sulphur on apparent N-use efficiency, yield and quality of oilseed rape (Brassica napus L.) grown on a calcareous soil. Eur. J. Agron. 12, 127-141. doi: 10.1016/S11610301(99)00052-0
Gilbert, S. M., Clarkson, D. T., Cambridge, M., Lambers, H., and Hawkesford, M. J. (1997). SO42- deprivation has an early effect on the content of ribulose1,5-biphosphate carboxylase/oxygenase and photosynthesis in young leaves of wheat. Plant Physiol. 115, 1231-1239.

Hawkesford, M. (2000). Plant responses to sulphur deficiency and the genetic manipulation of sulphate transporters to improve S-utilization efficiency. J. Exp. Bot. 342, 131-138. doi: 10.1093/jexbot/51.342.131

Iannucci, A., Russo, M., Arena, L., Di Fonzo, N., and Martiniello, P. (2002). Water deficit effects on osmotic adjustment and solute accumulation in leaves of annual clovers. Eur. J. Agron. 16, 111-122. doi: 10.1016/S1161-0301(01)00121-6

Khan, N. A., Anjum, N. A., Nazar, R., and Iqbal, N. (2009). Increased activity of ATP sulfurylase and increased contents of cysteine and glutathione reduce high cadmium-induced oxidative stress in mustard cultivar with high photosynthetic potential. Russ. J. Plant Physiol. 56, 670-677. doi: 10.1134/S1021443709050136

Khokon, M. A. R., Jahan, M. S., Rahaman, T., Hossain, M. A., Muroyama, D., Minami, I., et al. (2011). Allyl isothiocyanate (AITC) induces stomatal closure in Arabidiopsis. Plant Cell Environ. 34, 1900-1906. doi: 10.1111/j.13653040.2011.02385.x

Kim, T. H., Lee, B. R., Jung, W. J., Kim, K. Y., Avice, J. C., and Ourry, A. (2004). De novo protein synthesis in relation to ammonia and proline accumulation in water stressed white clover. Funct. Plant Biol. 31, 847-855. doi: 10.1071/FP04059

Kirkegaard, J. A., Hocking, P. J., Angus, J. F., Howe, G. N., and Gardner, P. A. (1997). Comparison of canola, Indian mustard and Linola in two contrasting environments. II. Break-crop and nitrogen effects on subsequent wheat crops. Field Crops Res. 52, 179-191. doi: 10.1016/S0378-4290(96)01057-X

Kusaka, M., Ohta, M., and Fujimura, T. (2005). Contribution of inorganic components to osmotic adjustment and leaf folding for drought tolerance in pearl millet. Physiol. Planta 125, 474-489. doi: 10.1111/j.1399-3054.2005.00578.x

Lee, B. R., Jin, Y. L., Avice, J. C., Cliquet, J. B., Ourry, A., and Kim, T. H. (2009). Increased proline loading to phloem and its effect on nitrogen uptake and assimilation in water stressed white clover (Trifolium repens). New Phytol. 182, 654-663. doi: 10.1111/j.1469-8137.2009.02795.x

Lee, B. R., Jin, Y. L., Park, S. H., Zaman, R., Zhang, Q., Avice, J. C., et al. (2015). Genotypic variation in N uptake and assimilation estimated by $15 \mathrm{~N}$ tracing water deficit-stressed Brassica napus. Envrion. Exp. Bot. 109, 73-79. doi: 10.1016/j.envexpbot.2014.08.004

Lee, B. R., Muneer, S., Jung, W. J., Avice, J. C., Ourry, A., and Kim, T. H. (2014). Partitioning of newly absorbed and previously stored nitrogen and sulphur under sulphate deficient nutrition. J. Plant Nutr. 37, 1702-1716. doi: 10.1080/01904167.2014.889148

Lee, B. R., Muneer, S., Kim, K. Y., Avice, J. C., Ourry, A., and Kim, T. H. (2013). S-deficiency responsive accumulation of amino acids is mainly due to hydrolysis of the previously synthesized proteins - not to de novo synthesis in Brassica napus. Physiol. Planta 147, 369-380. doi: 10.1111/j.1399-3054.2012.01669.x

Makino, A., Mae, T., and Ohira, K. (1985). Enzymic properties of ribulose-1,5bisphosphate carboxylase/oxygenase purified from rice leaves. Plant Physiol. 79, 57-61. doi: 10.1104/pp.79.1.57

Muneer, S., Lee, B. R., Kim, K. Y., Park, S. H., Zhang, Q., and Kim, T. H. (2014). Involvement of sulphur nutrition in modulating iron deficiency responses in photosynthetic organelles of oilseed rape (Brassica napus L.). Photosynth. Res. 119, 319-329. doi: 10.1007/s11120-013-9953-8

Nazar, R., Iqbal, N., Masood, A., Syeed, S., and Khan, N. A. (2011). Understanding the significance of sulphur in improving salinity tolerance in plants. Environ. Exp. Bot. 70, 80-87. doi: 10.1016/j.envexpbot.2010.09.011

Prosser, I. M., Schneider, A., Hawkesford, M. J., and Clakson, D. T. (1997). "Changes in nutrients composition, metabolite concentrations and enzyme activities in spinach in the early stages of S-deprivation," in Sulphur Metabolism in Higher Plants, eds W. J. Cram, L. J. De Kok, I. Stulen, C. Brunold, and H. Rennenberg (Leiden: Backhuys Publishers), 339-342.

Rausch, T., Gromes, R., Liedschulle, V., Muller, I., Bogs, J., Galovic, V., et al. (2007). Novel insight into the regulation of GSH biosynthesis in higher plants. Plant Biol. 9, 565-572. doi: 10.1055/s-2007-965580

Resurreccion, A. P., Makino, A., Bennett, J., and Mae, T. (2002). Effect of light intensity on the growth and photosynthesis of rice under different sulfur concentrations. Soil Sci. Plant Nutr. 48, 71-77. doi: $10.1080 / 00380768.2002 .10409173$ 
Saeidnia, S., and Gohari, A. R. (2012). Importance of Brassica napus as a medicinal food plant. J. Med. Plant Res. 6, 2700-2703.

Saito, K. (2000). Regulation of sulfate transport and synthesis of sulfurcontaining amino acids. Curr. Opin. Plant Biol. 3, 188-195. doi: 10.1016/S13695266(00)00063-7

Schnug, E., Haneklaus, S., and Murphy, D. P. L. (1993). Impact of sulphur fertilization on fertilizer nitrogen efficiency. Sulphur. Agric. 17, 8-12. doi: $10.1021 /$ jf071710s

Singh, S., Sharma, H., Goswami, A., Datta, S., and Singh, S. (2000). In vitro growth and leaf composition of grapevine cultivars as affected by sodium chloride. Biol. Plantarum 43, 283-286. doi: 10.1023/A:1002720714781

Szalai, G., Kellos, T., Galiba, G., and Kocsy, G. (2009). Glutathione as an antioxidant and regulatory molecule in plants under abiotic stress conditions. J. Plant Growth Regul. 28, 66-80. doi: 10.1007/s11033-012-2402-5

Tezara, W., Mitchell, V. J., Driscoll, S. D., and Lawlor, D. W. (1999). Water stress inhibits plant photosynthesis by decreasing coupling factor and ATP. Nature 401, 914-917. doi: 10.1038/44842

Warrilow, A. G. S., and Hawkesford, M. J. (1998). Separation, subcellular location and influence of sulphur nutrition on isoforms of cysteine synthase in spinach. J. Exp. Bot. 49, 1625-1636. doi: 10.1093/jxb/49.327.1625
Zhao, F. J., Bilsborrow, P. E., Evans, E. J., and McGrath, S. P. (1997). Nitrogen to sulfur ratio in rapeseed and in rapeseed protein and its use in diagnosing sulfur deficiency. J. Plant Nutr. 20, 549-558. doi: 10.1080/01904169709365273

Zhao, F. J., Hawkesford, M. J., and Mc Grath, S. P. (1999). Sulphur assimilation and effects on yield and quality of wheat. J. Cereal Sci. 1, 1-17. doi: $10.1006 /$ jcrs.1998.0241

Zuchi, S., Cesco, S., Varanini, Z., Pinton, R., and Astolfi, S. (2009). Sulphur deprivation limits Fe-deficiency responses in tomato plants. Planta 230, 85-94. doi: 10.1007/s00425-009-0919-1

Conflict of Interest Statement: The authors declare that the research was conducted in the absence of any commercial or financial relationships that could be construed as a potential conflict of interest.

Copyright $\odot 2016$ Lee, Zaman, Avice, Ourry and Kim. This is an open-access article distributed under the terms of the Creative Commons Attribution License (CC BY). The use, distribution or reproduction in other forums is permitted, provided the original author(s) or licensor are credited and that the original publication in this journal is cited, in accordance with accepted academic practice. No use, distribution or reproduction is permitted which does not comply with these terms. 